\title{
Pediococcus lolii sp. nov., isolated from ryegrass silage
}

\author{
Correspondence \\ Katsumi Doi \\ doi@agr.kyushu-u.ac.jp
}

\author{
Katsumi Doi, ${ }^{1}$ Yousuke Nishizaki, ${ }^{1}$ Yasuhiro Fujino, ${ }^{1}$ Toshihisa Ohshima, ${ }^{1}$ \\ Sadahiro Ohmomo ${ }^{2}$ and Seiya Ogata ${ }^{3}$
}

\author{
${ }^{1}$ Department of Genetic Resources Technology, Faculty of Agriculture, Kyushu University, 6-10-1 \\ Hakozaki, Higashi-ku, Fukuoka 812-8581, Japan \\ ${ }^{2}$ Asama Chemical Co. Ltd, 20-3 Nihonbashi-Kodenma-cho, Chuo-ku, Tokyo 103-0001, Japan \\ ${ }^{3}$ Department of Applied Microbial Technology, Faculty of Biotechnology and Life Science, Sojo \\ University, 4-22-1 Ikeda, Kumamoto 860-0082, Japan
}

A Gram-positive, coccus-shaped, lactic acid bacterium, strain NGRI $0510 Q^{\top}$, was isolated from ryegrass silage produced in Okinawa Prefecture, Japan. The cell is non-spore-forming, nonmotile, and occurs in pairs or tetrads. The strain is homofermentative and produces D- and L-lactic acid from glucose. Phylogenetic analysis based on 16S rRNA gene sequences revealed that strain NGRI $0510 Q^{\top}$ belongs to the genus Pediococcus and clusters within the Pediococcus acidilactici and Pediococcus pentosaceus group, with 98.2 and $96.9 \%$ sequence identity, respectively. DNA-DNA relatedness between strain NGRI $0510 Q^{\top}$ and $P$. acidilactici $\mathrm{JCM} 8797^{\top}$ and $P$. pentosaceus JCM $5890^{\top}$ was 19.3 and $17.3 \%$, respectively. Based on its phenotypic characteristics, phylogenetic relationship and DNA-DNA relatedness, NGRI 05100 ${ }^{\top}$ (=JCM $15055^{\top}=$ DSM $19927^{\top}$ ) represents the type strain of a novel species, for which the name Pediococcus lolii sp. nov. is proposed.
The members of the genus Pediococcus are typical lactic acid bacteria (LAB) in that they are Gram-positive, catalase-negative and oxidase-negative. At present, Pediococcus includes ten species: Pediococcus acidilactici (Tanasupawat et al., 1993), P. claussenii (Dobson et al., 2002), P. cellicola, $P$. damnosus, $P$. dextrinicus, $P$. ethanolidurans, $P$. inopinatus, $P$. parvulus, $P$. pentosaceus and $P$. stilesii (Franz et al., 2006). Two other species, the former $P$. halophilus and $P$. urinaeequi, have been reclassified as Tetragenococcus halophilus and Aerococcus urinaeequi. The members of the genus Pediococcus are homofermentative and produce lactic acid, but no $\mathrm{CO}_{2}$, from glucose and are not able to reduce nitrate. The uniformly spherical cells are never ovoid or elongated, and they differ from all other $\mathrm{LAB}$ by forming tetrads via alternate division in two perpendicular directions. Most of the species have been isolated from a large variety of plants and fruits, fermenting vegetables, beer and silage.

Silage production is an important technique for preserving plant materials with high nutritive value for use during the winter in cold and temperate regions and during the dry

Abbreviations: ERIC-PCR, enterobacterial repetitive intergenic consensus PCR; LAB, lactic acid bacteria, RAPD-PCR, random amplified polymorphic DNA PCR.

The GenBank/EMBL/DDBJ accession number for the $16 \mathrm{~S}$ rRNA gene sequence of strain NGRI $05100^{\top}$ is AB362985. season in tropical areas. It is based on natural fermentation whereby LAB ferment sugars to mainly lactic acid under anaerobic conditions. In the present study, we isolated and characterized a pediococcal strain from grass silage produced in Okinawa Prefecture, Japan. The strain exhibits distinct phenotypic characteristics, divergent sequences of the 16S rRNA gene and 16S-23S rRNA intergenic spacer region, and low rates of DNA-DNA hybridization. All of these characteristics distinguish this strain from presently known species in the genus Pediococcus.

Strain NGRI $0510 Q^{\mathrm{T}}$ was isolated from ryegrass silage produced on Ishigaki Island, Okinawa Prefecture, Japan. Isolation and purification was carried out with GYP agar (Tanaka et al., 1994) for 5 days at $37^{\circ} \mathrm{C}$ under aerobic conditions. Analogous cultivation conditions were used for subsequent experiments, unless indicated otherwise. Cell morphology was determined using scanning electron microscopy and phase-contrast microscopy. Bacterial growth was monitored by measuring the optical density at $660 \mathrm{~nm}$ using a Mini Photo 518R (TAITEC). D/L-Lactic acid and ethanol production and the glucose remaining in the medium were measured using HPLC according to the method of Tanaka \& Ohmomo (1994). Sugar fermentation patterns were determined using an API 50 CHL kit (bioMérieux) over a period of $72 \mathrm{~h}$. Preparation of cell wall and determination of peptidoglycan was carried out by the method described by Komagata \& Suzuki (1987), 
except that TLC was performed on cellulose sheets. All tests used for biochemical characterization were carried out at least in triplicate.

Genomic DNA was extracted and purified as described by Marmur (1961) with some modifications. To determine the genomic $\mathrm{G}+\mathrm{C}$ content, the purified DNA was digested using nuclease P1 (Yamasa), after which the $\mathrm{G}+\mathrm{C}$ content was determined by HPLC. DNA-DNA hybridization was carried out according to the method of Ezaki et al. (1989). The sequence of the 16S rRNA gene from the isolated strain was scanned using data registered in the DDBJ, GenBank and EMBL databases using DNASIS ver. 3.5 (Hitachi Software Engineering). GENETIX-MAC ver. 10 (GENETYX) was used to generate multiple alignments and to construct a phylogenetic tree. Distance matrices for the aligned sequences were calculated using the two-parameter method. The neighbour-joining method was used to construct the phylogenetic tree (Saitou \& Nei, 1987), and the robustness of individual branches was estimated by bootstrapping with 1000 replicates.

Random amplified polymorphic DNA (RAPD)-PCR and enterobacterial repetitive intergenic consensus (ERIC)-PCR were performed as we described previously (Fujino et al., 2008). RAPD-PCR was carried out using the Arbitrary Primer Set and Gene Taq FP polymerase (Nippon Gene). The primers AP-A-02 (5'-TGGATTGGTC-3'), AP-A-22 (5'-GATCGCATTG-3'), AP-A-24 (5'-GATCATGGTC-3') and AP-A-25 (5'-GATCATAGCG-3') were used in this study. The primers used for ERIC-PCR were ERIC1R (5'ATGTAAGCTCCTGGGGATTCAC- $3^{\prime}$ ) and ERIC2 (5'AAGTAAGTGACTGGGGTGAGCG-3') (Dalla-Costa et al., 1998).

Cells of strain NGRI $0510 \mathrm{Q}^{\mathrm{T}}$ were cocci with a diameter of $0.8-1.0 \mu \mathrm{m}$. They occurred singly and in pairs or tetrads, the last being typical for pediococci (Simpson \& Taguchi, 1995). Strain NGRI $0510 \mathrm{Q}^{\mathrm{T}}$ could not grow at $48{ }^{\circ} \mathrm{C}$ but did grow at $15{ }^{\circ} \mathrm{C}$. The optimum $\mathrm{pH}$ for growth was 6.0 6.8. Lactic acid [about $50 \%(-)$-D-/50\%(+)-L-] was produced from glucose by homofermentation, and the strain grew as a facultative anaerobe. No catalase activity was present. Phenotypic test results are summarized in Table 1. Growth at $48{ }^{\circ} \mathrm{C}$ and maltose fermentation are key for presumptive identification of $P$. pentosaceus and $P$. acidilactici, respectively (Holzapfel et al., 2006); thus, NGRI $0510 \mathrm{Q}^{\mathrm{T}}$ is distinguished from $P$. pentosaceus by its inability to produce acid from maltose, and from $P$. acidilactici by its inability to grow at $48{ }^{\circ} \mathrm{C}$. Cells of strain NGRI $0510 \mathrm{Q}^{\mathrm{T}}$ contain diaminopimelic acid in their peptidoglycan. The mean DNA G + C content of strain NGRI $0510 Q^{\mathrm{T}}$ was $41.0 \mathrm{~mol} \%$, which is within the range for genus Pediococcus (34-42 mol\%).

The complete 16S rRNA gene sequence of strain NGRI $0510 \mathrm{Q}^{\mathrm{T}}$ was compared with those of the most closely related species retrieved from the aforementioned databases. Construction of a phylogenetic tree rooted at Bifidobacterium bifidum DSM $20456^{\mathrm{T}}$ revealed that strain
Table 1. Characteristics that differentiate strain NGRI $0510 Q^{\top}$ from related pediococci species

Taxa: 1, P. lolii sp. nov.; 2, P. acidilactici; 3, P. pentosaceus; 4, P. stilesii; 5, P. claussenii. Data for Pediococcus species were obtained from Tanasupawat et al. (1993), Dobson et al. (2002) and Franz et al. (2006). +, Positive; -, negative; w, weak reaction.

\begin{tabular}{|lccccc|}
\hline Characteristic & $\mathbf{1}$ & $\mathbf{2}$ & $\mathbf{3}$ & $\mathbf{4}$ & $\mathbf{5}$ \\
\hline Acid from: & & & & & \\
$\quad$ L-Arabinose & + & + & + & - & - \\
Lactose & - & - & - & - & - \\
Galactose & + & + & + & + & - \\
Sucrose & - & - & + & - & - \\
D-Xylose & + & + & W & - & - \\
Rhamnose & + & - & - & - & - \\
Trehalose & - & + & + & - & + \\
Raffinose & - & - & W & - & - \\
Maltose & - & - & + & + & + \\
Melibiose & - & - & + & - & - \\
Growth at $48{ }^{\circ}$ C & - & + & - & - & - \\
Lactate formed & DL & DL & DL & DL & L $(+)$ \\
DNA G + C content & 41.0 & 43.5 & 37.8 & 38.0 & 40.5 \\
$\quad($ mol\%) & & & & & \\
\hline
\end{tabular}

NGRI $0510 Q^{\mathrm{T}}$ clusters within the $P$. acidilactici-P. pentosaceus $-P$. stilesii group (Fig. 1). The similarities of the 16S rRNA gene sequence of strain NGRI $0510 \mathrm{Q}^{\mathrm{T}}$ to those of P. acidilactici DSM $20284^{\mathrm{T}}$, P. pentosaceus DSM

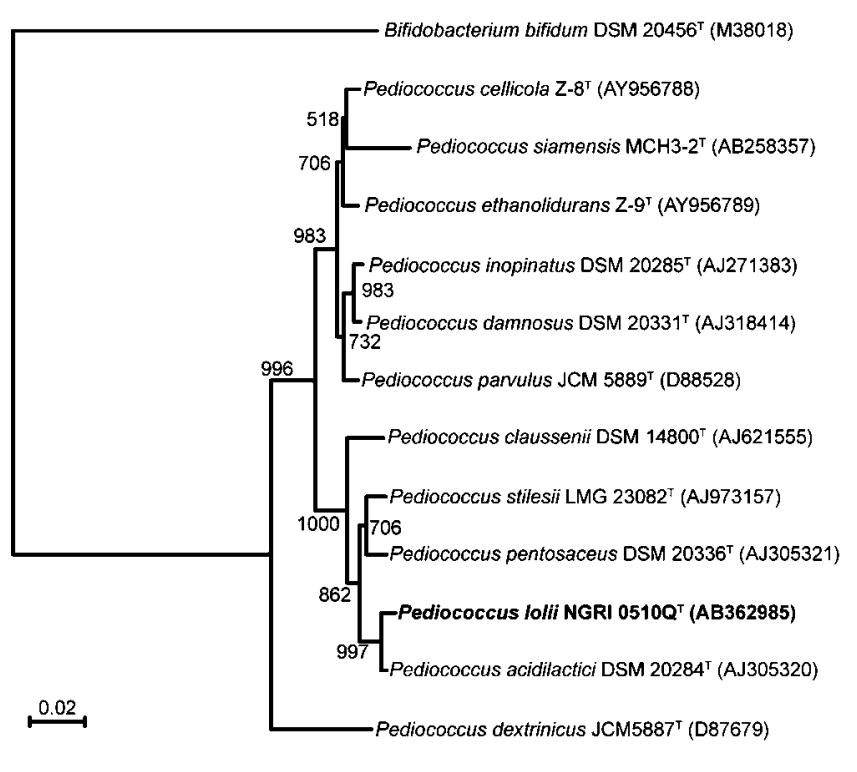

Fig. 1. Neighbour-joining phylogenetic tree based on the $16 \mathrm{~S}$ rRNA gene sequences. The relationships between strain NGRI $0510 Q^{\top}$ and related species are shown. Bifidobacterium bifidum DSM $20456^{\top}$ was used as an outgroup. Bootstrap values based upon 1000 replicates are included at the major branch points. Bar, 0.02 nucleotide substitutions per site. 
$20336^{\mathrm{T}}$ and P. stilesii LMG $23082^{\mathrm{T}}$ were $98.2,96.9$ and $96.3 \%$, respectively. Given the high degree of similarity between the 16S rRNA gene sequence of strain NGRI $0510 \mathrm{Q}^{\mathrm{T}}$ and those of species of pediococci, the levels of DNA-DNA relatedness between the isolate and $P$. acidilactici DSM $20284^{\mathrm{T}}$ and P. pentosaceus DSM $20336^{\mathrm{T}}$ were determined and found to be 19.3 and $17.3 \%$, respectively, which is lower than the DNA-DNA relatedness threshold for a species $(70 \%)$ as recommended by Wayne et al. (1987).

All RAPD-PCR and ERIC-PCR fingerprints for strains NGRI $0510 \mathrm{Q}^{\mathrm{T}}, \quad P$. acidilactici DSM $20284^{\mathrm{T}}$ and $P$. pentosaceus DSM $20336^{\mathrm{T}}$ were distinctly different (Fig. 2). In ERIC-PCR fingerprints, a few similarly sized fragments were observed between strain NGRI $0510 Q^{\mathrm{T}}$ and $P$. acidilactici DSM $20284^{\mathrm{T}}$, but obvious differentiation was seen in the RAPD-PCR pattern. Thus strain NGRI $0510 \mathrm{Q}^{\mathrm{T}}$ could be separated from $P$. acidilactici DSM $20284^{\mathrm{T}}$ and $P$. pentosaceus DSM $20336^{\mathrm{T}}$ by genotyping.

Based on its phenotypic characteristics, phylogenetic relationship and DNA-DNA relatedness, a novel species of the genus Pediococcus, Pediococcus lolii sp. nov., is proposed to accommodate strain NGRI $0510 \mathrm{Q}^{\mathrm{T}}$.

\section{Description of Pediococcus lolii sp. nov.}

Pediococcus lolii (lo'li.i. L. gen. n. lolii of ryegrass).

Cells are Gram-positive, catalase-negative, non-motile and non-spore-forming. The spherical cells occur in pairs or tetrads, and are $0.8-1.0 \mu \mathrm{m}$ in diameter after $24 \mathrm{~h}$ growth in GYP broth under aerobic conditions at $37^{\circ} \mathrm{C}$. Colonies are off-white, low-convex, circular, entirely opaque, and about $1-2 \mathrm{~mm}$ in diameter after $24 \mathrm{~h}$ of cultivation on GYP agar at $37{ }^{\circ} \mathrm{C}$. The cells grow well in liquid or solid

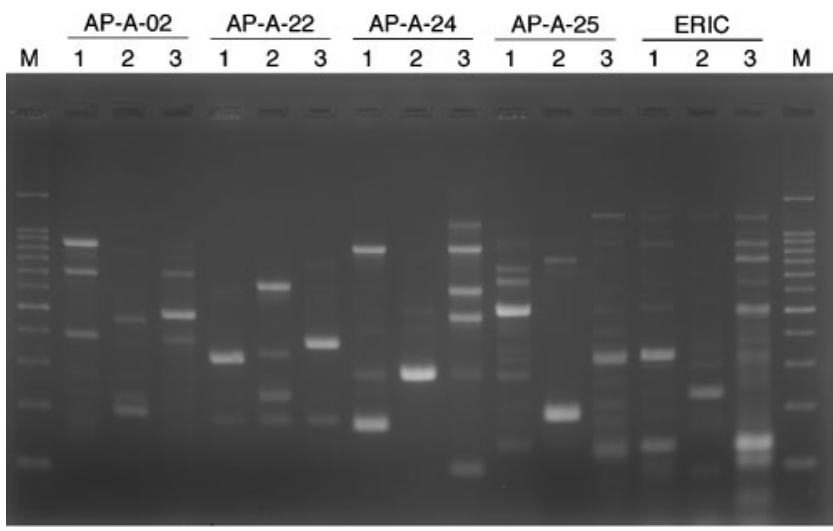

Fig. 2. RAPD-PCR and ERIC-PCR fingerprinting of strain NGRI $0510 Q^{\top}$ and type strains of related species. Primers AP-A-02, APA-22, AP-A-24 and AP-A-25 were used. Lanes: $M$, size markers (200 bp DNA ladder; TOYOBO); 1, NGRI 0510Q ${ }^{\top} ; 2, P$. pentosaceus DSM $20336^{\top}$; $3, P$. acidilactici DSM $20284^{\top}$.
GYP under facultatively anaerobic conditions. Growth occurs at $15-43{ }^{\circ} \mathrm{C}$, with optimum growth occurring at $37{ }^{\circ} \mathrm{C}$. Lactic acid [about $50 \%(-)$-D- $/ 50 \%(+)$-L-] is produced from glucose by homofermentation. Lactic acid, but not gas, is produced from glucose fermentation. The optimum $\mathrm{pH}$ for growth is 6.0-6.8 (range, $\mathrm{pH} 4.0-8.0$ ). Acid is produced from L-arabinose, ribose, D-xylose, galactose, glucose, fructose, $\mathrm{N}$-acetylglucosamine, amygdalin, arbutin, aesculin, salicin, cellobiose and gentiobiose. The peptidoglycan structure is of the diaminopimelic acid type, and the DNA $\mathrm{G}+\mathrm{C}$ content of the type strain is $41.0 \mathrm{~mol} \%$.

The type strain NGRI $0510 \mathrm{Q}^{\mathrm{T}}\left(=\mathrm{JCM} \quad 15055^{\mathrm{T}}=\mathrm{DSM}\right.$ $19927^{\mathrm{T}}$ ) was isolated from ryegrass silage produced on Ishigaki Island in Okinawa Prefecture, Japan.

\section{Acknowledgements}

We thank Dr J. P. Euzéby, Ecole Nationale Vétérinaire, Toulouse, France for his suggestion regarding the nomenclature for the novel species. This research was supported in part by Grants-in-Aid for Scientific Research (A) 07556094 of MEXT, Japan.

\section{References}

Dalla-Costa, L. M., Irino, K., Rodrigues, J., Rivera, I. N. \& Trabulsi, L. R. (1998). Characterisation of diarrhoeagenic Escherichia coli clones by ribotyping and ERIC-PCR. J Med Microbiol 47, 227-234.

Dobson, C. M., Deneer, H., Lee, S., Hemmingsen, S., Glaze, S. \& Ziola, B. (2002). Phylogenetic analysis of the genus Pediococcus, including Pediococcus claussenii sp. nov., a novel lactic acid bacterium isolated from beer. Int J Syst Evol Microbiol 52, 2003-2010.

Ezaki, T., Hashimoto, Y. \& Yabuuchi, E. (1989). Fluorometric deoxyribonucleic acid-deoxyribonucleic acid hybridization in microdilution wells as an alternative to membrane filter hybridization in which radioisotopes are used to determine genetic relatedness among bacterial strains. Int J Syst Bacteriol 39, 224-229.

Franz, C. M., Vancanneyt, M., Vandemeulebroecke, K., De Wachter, M., Cleenwerck, I., Hoste, B., Schillinger, U., Holzapfel, W. H. \& Swings, J. (2006). Pediococcus stilesii sp. nov., isolated from maize grains. Int J Syst Evol Microbiol 56, 329-333.

Fujino, Y., Kawatsu, R., Inagaki, F., Umeda, A., Yokoyama, T., Okaue, Y., Iwai, S., Ogata, S., Ohshima, T. \& Doi, K. (2008). Thermus thermophilus TMY isolated from silica scale taken from a geothermal power plant. J Appl Microbiol 104, 70-78.

Holzapfel, W., Franz, C., Ludwig, W., Back, W. \& Dicks, L. (2006). The genera Pediococcus and Tetragenococcus. In The Prokaryotes, 3rd edn, vol. 4, pp. 229-266. Edited by M. Dworkin, S. Falkow, E. Rosenberg, K.-H. Schleifer \& E. Stackebrandt. New York: SpringerVerlag.

Komagata, K. \& Suzuki, K. (1987). Lipid and cell-wall analysis in bacterial systematics. Methods Microbiol 19, 161-207.

Marmur, J. (1961). A procedure for the isolation of deoxyribonucleic acid from microorganisms. J Mol Biol 3, 208-218.

Saitou, N. \& Nei, M. (1987). The neighbor-joining method: a new method for reconstructing phylogenetic trees. Mol Biol Evol 4, 406425.

Simpson, W. J. \& Taguchi, H. (1995). The genus Pediococcus, with notes on the genera Tetragenococcus and Aerococcus. In The Genera of 
Lactic Acid Bacteria, pp. 125-172. Edited by B. J. B. Wood \& W.-H. Holzapfel. London: Blackie Academic \& Professional.

Tanaka, O. \& Ohmomo, S. (1994). A repeatable model system for silage fermentation in culture tubes. Biosci Biotechnol Biochem 58, 1407-1411.

Tanaka, O., Kimura, H., Takahashi, E., Ogata, S. \& Ohmomo, S. (1994). Screening of lactic acid bacteria for silage inoculants by using a model system of silage fermentation. Biosci Biotechnol Biochem 58, $1412-1415$.
Tanasupawat, S., Okada, S., Kozaki, M. \& Komagata, K. (1993). Characterization of Pediococcus pentosaceus and Pediococcus acidilactici strains and replacement of the type strain of P. acidilactici with the proposed neotype DSM 20284. Int J Syst Bacteriol 43, 860-863.

Wayne, L. G., Brenner, D. J., Colwell, R. R., Grimont, P. A. D., Kandler, O., Krichevsky, M. I., Moore, L. H., Moore, W. E. C., Murray, R. G. E. \& other authors (1987). International Committee on Systematic Bacteriology. Report of the ad hoc committee on reconciliation of approaches to bacterial systematics. Int J Syst Bacteriol 37, 463-464. 